\title{
HUBUNGAN ANTARA PENDAPATAN NASIONAL DAN INVESTASI DI INDONESIA (Suatu Kajian Ekonomi Makro dengan Model VAR)
}

\author{
Muhammad Kholis ${ }^{1)}$ \\ Diah Astuti2) \\ Rini Febrianti3) \\ 1)UPBJJ Universitas Terbuka Surakarta \\ 2)UPBJJ Universitas Terbuka Yogyakarta \\ 3)Universitas Terbuka \\ e-Mail: mkholis@ut.ac.id
}

\begin{abstract}
Some previous studies suggested pros and cons regarding the correlation between investment and economic growth. The study is to determined if investment in Indonesia has a positive influence on the economic growth in Indonesia. This study uses a Vector Auto Regression/ VAR. Variables used in this study include economic growth, investment growth, export growth and import growth. The calculations show that investment growth and export growth has a positive effect on economic growth, whereas import growth has a negative effect on economic growth in Indonesia. These results indicate that the driver of economic growth is investment and exports. Thus, the government must create a climate to increase the role of investment in economic growth.
\end{abstract}

Keywords: economic growth, export, import, investment, vector autoregression.

\begin{abstract}
ABSTRAK
Beberapa kajian terdahulu menyatakan adanya pro dan kontra mengenai korelasi antara investasi dengan pertumbuhan ekonomi. Hipotesis yang ingin dibuktikan dalam kajian ini adalah investasi di Indonesia memiliki pengaruh yang positif dengan pertumbuhan ekonomi di Indonesia. Penelitian ini menggunakan metode Vector Auto Regression (VAR). Variabel yang digunakan dalam penelitian ini antara lain pertumbuhan ekonomi, pertumbuhan investasi, pertumbuhan ekspor dan pertumbuhan impor. Hasil perhitungan menunjukkan bahwa pertumbuhan investasi dan pertumbuhan ekspor memiliki pengaruh positif terhadap pertumbuhan ekonomi, sebaliknya pertumbuhan impor memiliki pengaruh negative terhadap pertumbuhan ekonomi di Indonesia. Hasil ini mengindikasikan bahwa pendorong pertumbuhan ekonomi adalah investasi dan ekspor. Dengan demikian pemerintah harus menciptakan iklim untuk meningkatkan peran investasi dalam pertumbuhan ekonomi.
\end{abstract}

Kata kunci: ekspor, impor, investasi, pertumbuhan ekonomi, vector auto regression.

Sejak tahun 1970 pembangunan ekonomi mengalami redefinisi. Sejak tahun tersebut muncul pandangan baru yaitu tujuan utama dari usaha-usaha pembangunan ekonomi tidak lagi menciptakan tingkat pertumbuhan GNP yang setinggi-tingginya, melainkan penghapusan atau pengurangan 
tingkat kemiskinan, penanggulangan ketimpangan pendapatan, dan penyediaan lapangan kerja dalam konteks perekonomian yang terus berkembang (Todaro dan Smith, 2006). Pertumbuhan ekonomi merupakan proses perubahan kondisi perekonomian suatu negara secara berkesinambungan menuju keadaan yang lebih baik selama periode tertentu. Pertumbuhan ekonomi dapat diartikan juga sebagai proses kenaikan kapasitas produksi suatu perekonomian yang diwujudkan dalam bentuk kenaikan pendapatan nasional. Adanya pertumbuhan ekonomi merupakan indikasi keberhasilan pembangunan ekonomi. Pertumbuhan ekonomi ditandai dengan perubahan pendapatan nasional.

Dalam teori ekonomi pembangunan diketahui bahwa tingkat pertumbuhan ekonomi dan investasi mempunyai hubungan timbal balik yang positif. Hubungan timbal balik tersebut terjadi oleh karena di satu pihak, semakin tinggi pertumbuhan ekonomi suatu negara, berarti semakin besar bagian dari pendapatan yang bisa ditabung, sehingga investasi yang tercipta akan semakin besar pula. Dalam kasus ini, investasi merupakan fungsi dari pertumbuhan ekonomi. Di lain pihak, semakin besar investasi suatu negara, baik asing maupun dalam negeri akan semakin besar pula tingkat pertumbuhan ekonomi yang bisa dicapai. Dengan demikian, pertumbuhan merupakan fungsi investasi (Hadi, 2003).

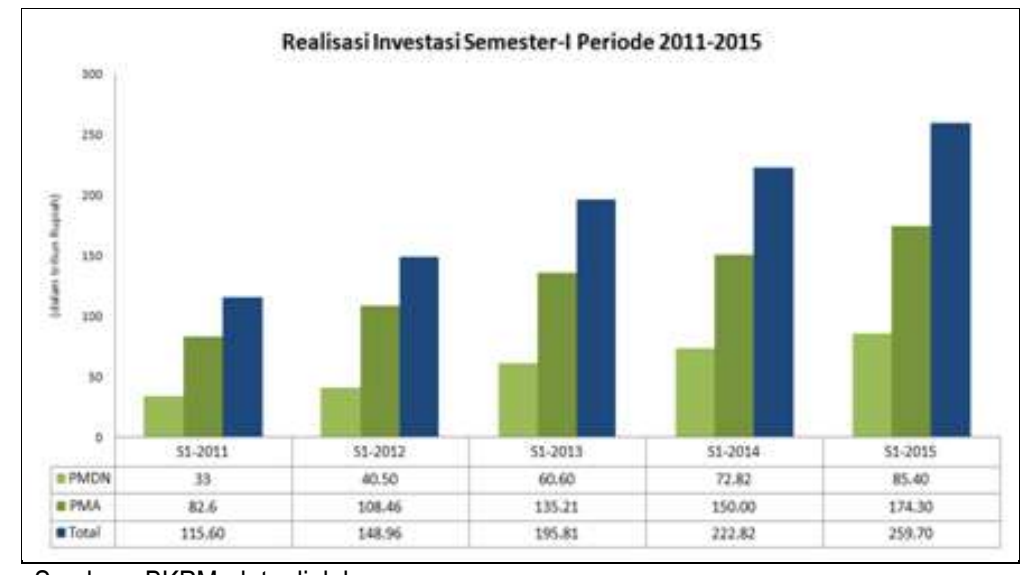

Sumber : BKPM, data diolah

Gambar 1. Realisasi investasi di Indonesia

Data mengenai perkembangan investasi asing di Indonesia dapat dilihat pada Gambar 1. Dari Gambar 1 diketahui bahwa investasi di Indonesia menunjukkan perkembangan yang menggembirakan. Berbagai upaya dilakukan pemerintah Indonesia untuk meningkatkan iklim investasi di Indonsia seperti menyederhanakan birokrasi. Data Badan Koordinasi Penanaman Modal (BKPM) ternyata menunjukkan bahwa investasi Penanaman Modal Asing (PMA) pada semester I 2015 tumbuh 16,1 persen dibanding periode yang sama tahun sebelumnya, menjadi Rp174,2 triliun. Sementara itu, investasi penanaman modal dalam negeri (PMDN) pun naik 17,4 persen menjadi Rp85,5 triliun. Jika dilihat secara historis, investasi PMDN bahkan mengalami pertumbuhan lebih tinggi dibandingkan PMA. Realisasi investasi PMDN di semester I 2015 naik lebih dari dua kali lipat dibandingkan semester I 2012.

Investasi diyakini sebagai salah satu faktor yang dapat mendorong pertumbuhan ekonomi. Implikasi kebijakan dari adanya hubungan timbal balik antara tingkat investasi dan tingkat 
pendapatan tersebut adalah pada pembuatan proyeksi kebutuhan investasi tahunan dan target pertumbuhan ekonomi. Dengan memegang asumsi bahwa hubungan timbal balik tersebut terjadi, maka dalam membuat proyeksi investasi harus memperhitungkan variabel pertumbuhan ekonomi; dan sebaliknya dalam memproyeksikan angka pertumbuhan ekonomi, variabel investasi harus dijadikan salah satu faktor penentu.

Investasi sering juga disebut penanaman modal atau pembentukan modal. Investasi dapat diartikan sebagai pengeluaran penanam-penanam modal atau perusahaan untuk membeli barangbarang modal atau perlengkapan-perlengkapan produksi untuk menambah kemampuan memproduksi barang-barang dan jasa-jasa yang tersedia dalam perekonomian (Sukirno, 2004:121). Jadi sebuah pengeluaran dapat dikatakan sebagai investasi jika ditujukan untuk meningkatkan kemampuan produksi. Investasimerupakanhal yang pentingdalamperekonomian.

Secara teoritis ada tiga faktor utama yang mempengaruhi keputusan seseorang untuk melakukan investasi. Pertama, revenues (pendapatan), yaitu sejauh mana ia akan memperoleh pendapatan yang memadai dari modal yang ditanamkannya. Kedua, cost (biaya), yang terutama ditentukan oleh tingkat suku bunga dan pajak, walaupun dalam operasionalnya ditentukan juga oleh berbagai biaya lain yang ditemui di lapangan. Ketiga, expectations (harapan-harapan), yaitu bagaimana harapan di masa datang dari investasinya. Jadi, investor yang serius dalam penanaman modal langsung (direct investment) tidak hanya "hit and run", tetapi berhitung jauh ke depan. la memperhitungkan situasi-situasi pada masa mendatang yang dapat mempengaruhi investasinya, termasuk perubahan situasi politik (Hamid, 2008).

Dari berbagai faktor tersebut pertimbangan utama investor untuk melakukan investasi adalah keuntungan(firms invest to earn profits). Kemungkinan memperoleh keuntungan itulah yang dikaitkan dengan setiap variabel yang ada di suatu lokasi sebelum melakukan investasi. Dengan memasukkan semua variabel yang ada, investor bisa memperkirakan keuntungan dengan berbagai model pendekatan, seperti pendekatan present value, marginal efficiency of capital, atau untuk perekonomian nasional biasanya dengan pendekatan capital-output ratio dari Harrod-Domar. Betapa pun rawannya suatu daerah, jika dalam perhitungan dimungkinkan memperoleh laba, maka sangat mungkin investor masih bersedia datang. Investor akan mengkalkulasi expected risk dan expected profit-nya. Seaman-amannya suatu wilayah, jika tidak ada peluang ekonomi yang bisa diharapkan untuk memperoleh keuntungan maka investor tidak akan masuk. Namun demikian, investor tentu akan memilih lokasi yang menguntungkan dan aman, yaitu yang memiliki country risk-nya rendah.

Saat ini masih terjadi pro dan kontra mengenai hubungan antara investasi dengan pertumbuhan ekonomi. Kajian yang dilakukan oleh Gani dan Din (2006) di Pakistan dan Akhmetova, et al (2010) yang melakukan studi di Kazakhstan menyatakan bahwa investasi tidak memiliki pengaruh signifikan terhadap pertumbuhan ekonomi. Sementara itu kajian yang dilakukan oleh Rao (2004) menganalisis korelasi antara tingkat pertumbuhan dengan rasio investasi terhadap output di negara Fiji disimpulkan hasil bahwa meningkatnya pertumbuhan ekonomi akan meningkatkan investasi. Temuan ini didukung oleh Gharana dan Adhikari (2011) serta Liu, et al (2001) yang melakukan studi di China. Sementara itu Rao (2004) menganalisis korelasi antara tingkat pertumbuhan dengan rasio investasi terhadap output di negara Fiji disimpulkan hasil bahwa meningkatnya pertumbuhan ekonomi cenderung meningkatkan investasi. Temuan ini serupa dengan kajian yang dilakukan oleh Gharana dan Adhikari (2010) menggunakan Toda-Yamamoto-DoladoLutkephol Augmented VAR Technique for Testing Granger Causality menjelaskan adanya korelasi yang kuat antara investasi dengan pertumbuhan ekonomi di China. Temuan yang diperoleh Borensztein et al (1998) serta Effendi dan Soemantri (2003) yang menyatakan bahwa keberadaan 
investasi asing langsung justru meningkatkan pertumbuhan ekonomi. Temuan ini didukung oleh Alfaro,et al (2000) yang juga menyatakan bahwa kahadiran investasi asing langsung berdampak positip terhadap pertumbuhan ekonomi, terutama dalam sektor keuangan.

Beberapa kajian terdahulu masih mengisyaratkan adanya pro dan kontra mengenai korelasi antara investasi dengan pertumbuhan ekonomi yang merupakan proksi dari pendapatan. Hipotesis yang ingin dibuktikan kebenarannya secara statistik dalam penelitian ini adalah bahwa investasi di Indonesia memiliki pengaruh yang positif dengan investasi di Indonesia. Fokus kajian ini adalah seluruh investasi yang ada di Indonesia, baik PMA maupun PMDN. Berdasarkan latar belakang tersebut maka diperlukan kajian untuk menganalisis hubungan antara pertumbuhan ekonomi dengan investasi yang ada di Indonesia menggunakan metode VAR. Metode VAR diyakini mampu menjawab permasalahan yang akan diteliti karena memahami adanya hubungan timbal balik (interrelationship) antara variabel-variabel ekonomi, maupun di dalam pembentukan model ekonomi berstruktur.

Data yang digunakan dalam penelitian ini adalah pertumbuhan GDP yang merupakan proksi dari pendapatan nasional, pertumbuhan investasi di Indonesia, pertumbuhan ekspor dan pertumbuhan impor. Rentang waktu penelitian adalah mulai tahun 1990 sampai 2013. Data diperoleh dari Badan Kebijakan Penanaman Modal (BKPM) Indonesia, International Monetary Fund (IMF), Bank Indonesia dan BPS.

\section{Analisis Vector Auto Regression}

Metode Vector Autoregression (VAR) pertama kali dikembangkan oleh Christoper Sims (1980). Kerangka analisis yang praktis dalam model ini akan memberikan informasi yang sistematis dan mampu menaksir dengan baik informasi dalam persamaan yang dibentuk dari data time series (Lestari, 2005). VAR bisa dipadankan dengan suatu model persamaan simultan, karena dalam VAR kita mempertimbangkan beberapa variabel endogen secara bersama-sama dalam suatu model. Perbedaannya dengan model persamaan simultan biasa adalah bahwa dalam analisis VAR masingmasing variabel selain diterangkan oleh nilainya di masa lampau, juga dipengaruhi oleh nilai masa lalu dari semua variabel endogen lainnya dalam model yang diamati. Di samping itu, dalam VAR biasanya tidak ada variabel eksogen dalam model tersebut.

Keunggulan dari analisis VAR antara lain adalah: (1) Metode ini sederhana, kita tidak perlu khawatir untuk membedakan mana variabel endogen, mana variabel eksogen; (2) Estimasinya sederhana, dimana metode OLS biasa dapat diaplikasikan pada tiap-tiap persamaan secara terpisah; (3) Hasil perkiraan (forecast) yang diperoleh dengan menggunakan metode ini dalam banyak kasus lebih bagus dibandingkan dengan hasil yang didapat dengan menggunakan model persamaan simultan yang kompleks sekalipun. Selain itu, VAR Analysis juga merupakan alat analisis yang sangat berguna, baik di dalam memahami adanya hubungan timbal balik (interrelationship) antara variabel-variabel ekonomi, maupun di dalam pembentukan model ekonomi berstruktur.

Untuk memahami analisis VAR, perhatikan sistem dua variabel sederhana (the simple bivariate system) berikut (Hadi, 2003):

$$
\begin{aligned}
& Y_{t}=a_{10}+a_{11} Y_{t-1}+a_{12} Z_{t-1}+a_{13} Y_{t-2}+a_{14} Z_{t-2}+e_{y t} \\
& Z_{t}=a_{20}+a_{21} Y_{t-1}+a_{22} Z_{t-1}+a_{23} Y_{t-2}+a_{24} Z_{t-2}+e_{z t}
\end{aligned}
$$

Dimana:

$Y_{t} \quad=$ PDB pada tahun $t$

$\mathrm{Z}_{\mathrm{t}} \quad=$ investasi pada tahun $\mathrm{t}$ 
$Y_{t-n} \quad=$ PDB pada tahun $t-n$

$Z_{t-n} \quad=$ investasi pada tahun $t-n$

$a_{10}, a_{20}=$ konstanta

$e_{y t}, e_{z t}=$ faktor gangguan

Dua persamaan diatas menunjukkan bahwa dua variabel ekonomi yang diamati, yakni produk domestik bruto (PDB) dan investasi, saling mempengaruhi satu sama lain. Sebagai contoh, PDB dalam tahun $t\left(Y_{t}\right)$ dipengaruhi oleh PDB dalam periode sebelumnya $\left(Y_{t-1}\right.$ dan $\left.Y_{t-2}\right)$, dan oleh investasi dalam tahun sebelumnya $\left(Z_{t-1}\right.$ dan $\left.Z_{t-2}\right)$. Demikian pula, investasi dalam tahun $t\left(Z_{t}\right)$ dipengaruhi oleh investasi dalam tahun sebelumnya $\left(Z_{t-1}\right.$ dan $\left.Z_{t-2}\right)$, dan oleh PDB dalam periode sebelumnya $\left(\mathrm{Y}_{\mathrm{t}-1}\right.$ dan $\left.\mathrm{Y}_{\mathrm{t}-2}\right)$.

Secara umum, model VAR dengan $n$ variabel endogen bias ditulis sebagai berikut:

$\mathrm{Y}_{1 t}=\beta_{01}+\sum_{i=1}^{p}+\beta_{i 1} \mathrm{Y}_{1 t-i}+\sum_{i=1}^{p}+\alpha_{i 1} \mathrm{Y}_{2 t-i}+\ldots+\sum_{i=1}^{p}+\eta_{i 1} \mathrm{Y}_{\mathrm{n} t-i}+\mathrm{e}_{1 t}$ dimana $Y=$ variabel dan $p=$ panjang kelambanan.

Penamaan model VAR ini karena di sebelah kanan persamaan hanya terdiri dari kelambanan variabel di sebelah kiri sehingga disebut dengan auto regression.S edangkan kata vector karena berhubungan dengan dua atau lebih variable dalam model. Model VAR adalah model persamaan regresi yang menggunakan data time series.

Penelitian ini akan mengembangkan model yang yang sudah dilakukan oleh Hadi (2003) dan mengkombinasikan dengan kajian yang sudah dilakukan oleh Samanun (1994) serta Effendi dan Sumantri (2003). Model ini didasarkan pada model Solow dan Denison yang diderivasi dari fungsi produksi dari pertumbuhan input untuk menghitung pertumbuhan output. Mengikuti asumsi sumber pertumbuhan (sources of growth assumption) yang diperkenalkan oleh Solow dan Denison maka estimasi model investasi asing langsung dalam penelitian ini adalah:

$$
\operatorname{grgdp}_{i t}=\sum_{p=1} \alpha_{1} g I N V_{i t}+\alpha_{2} g E X_{i t}+\alpha_{3} g I M_{i t}+\varepsilon_{i t}
$$

Dimana:

$\operatorname{grgdp}_{\text {it }}$ adalah pertumbuhan GDP riil di Indonesia pada periode t.

$g I N V_{i t}$ adalah pertumbuhan investasi di Indonesia pada periode $\mathrm{t}$

$g E X_{i t}$ adalah pertumbuhan ekspor di Indonesia pada periode $t$

$g I M_{i t}$ adalah pertumbuhan impor di Indonesia pada periode $\mathrm{t}$

$\varepsilon_{i t} \quad$ adalah intersep

Hipotesis yang dikemukakan dalam penelitian ini adalah sebagai berikut:

1. Pertumbuhan investasi memiliki pengaruh positif terhadap pertumbuhan ekonomi. Pertumbuhan ekonomi dalam kajian ini merupakan proksi dari pendapatan nasional di Indonesia. Proposisi dari hipotesis ini didasari oleh kajian yang sudah dilakukan Effendi dan Sumantri (2003) yang menyatakan bahwa investasi di Indonesia memiliki pengaruh positif terhadap pertumbuhan ekonomi.

2. Pertumbuhan ekspor memiliki pengaruh positif terhadap pertumbuhan ekonomi. Proposisi yang mendasari hipotesis ini adalah bahwa semakin banyak ekspor maka akan berkorelasi positif 
terhadap pertumbuhan ekonomi yang dalam kajian ini merupakan proksi dari pendapatan nasional.

3. Pertumbuhan impor memliki pengaruh negatif terhadap pertumbuhan ekonomi. Semakin banyak impor maka semakin banyak aliran dana keluar negeri yang pada gilirannya akan menurunkan pendapatan nasional.

\section{Uji Stasioner Data (Unit Root Test)}

Uji stasioner data yang banyak digunakan adalah Unit Root Test yang pertama kali dikembangkan oleh Dickey-Fuller (DF). Uji stasioner akan dilakukan dengan metode ADF (Augmented Dickey-Fuller) sesuai dengan bentuk tren variabel di dalamnya. Prosedur untuk menentukan apakah data stasioner atau tidak dengan cara membandingkan antara nilai statistik ADF dengan nilai kritis distribusi statistik MacKinnon. Jika nilai absolute statistik ADF lebih besar dari nilai kritis MacKinnon, maka data menunjukkan stasioner. Jika sebaliknya, nilai absolut ADF lebih kecil dari nilai kritis MacKinnon maka data tidak stasioner (Widarjono, 2009).

Jika ternyata data series tidak stasioner maka perlu dilakukan differencing terhadap data yang tidak stasioner dan kembali dilakukan Unit Root Test dengan ADF lagi. Meskipun demikian, differencing yang dilakukan harus dapat diinterpresentasikan agar penelitian tidak kehilangan makna. Suatu data dikatakan stasioner artinya data tersebut memiliki mean yang tetap dan stabil, random error=0, sehingga model yang digunakan tidak memiliki regresi palsu (sporious regression).

Kombinasi dari dua seri yang tidak stasioner, akan bergerak ke arah yang sama menuju ekuilibrium jangka panjangnya dan diferensiasi diantara kedua seri tersebut akan konstan. Jika demikian halnya, seri ini dikatakan saling berkointegrasi. Tes kointegrasi pada penelitian ini didasarkan pada pendekatan vector autoregressions (VAR) Johansen. Jika vektor $X t$ adalah vektor variabel endogen dalam VAR dengan panjang lag $p$, maka:

$$
X_{t}=A_{1} X_{t-1}+A_{2} X_{t-2}+\ldots .+A_{p} X_{t-p}+\beta Y_{t}+\varepsilon_{t}
$$

Dimana:

$X t=$ vektor variabel endogen

$A p=$ parameter matriks

$\beta Y t=$ vektor dari deterministic variable

$\varepsilon t=$ vektor innovations

Spesifikasi VAR ini dapat dinyatakan dalam bentuk first difference sebagai berikut (Stock and Watson, 2001):

$$
\Delta X_{t}=\Pi X_{t-1}+\sum_{i=j}^{p-1} \Gamma_{i} \Delta X_{t-1}+\beta Y_{t}+\varepsilon_{t}
$$

Dimana:

$$
\begin{aligned}
& \Pi=\sum_{i=1}^{p} A_{1}-I \\
& \Gamma_{i}=-\sum_{j=i+1}^{p} A_{j}, \text { dan } \\
& \mathrm{I}=\text { matriks identitas }
\end{aligned}
$$


Jika tidak terdapat hubungan kointegrasi, model unrestricted VAR dapat diaplikasikan.

Tetapi, bila terdapat hubungan kointegrasi antar seri, model Vector Error Correction (VECM) yang dipergunakan. Jumlah vektor kointegrasi diperoleh dengan melihat signifikansi dari $\Pi$, melalui dua likelihood test.

maximum eigenvalue $=\lambda \max =-T \ln \left(1-\hat{\lambda}_{r+1}\right)$

dimana $\hat{\lambda}$ adalah nilai estimasi eigenvalue yang diperoleh dari estimasi terhadap matriks $\Pi \operatorname{dan} \mathrm{T}=$ jumlah observasi.

Uji berikutnya adalah trace test (uji teras) yaitu mengukur jumlah vektor kointegrasi dalam data, dengan menggunakan pengujian pangkat matriks kointegrasi, dinyatakan sebagai berikut :

$$
\text { trace statistic }=\lambda_{\text {trace }}=-T \sum_{i-r+1}^{n} \ln \left(1-\hat{\lambda}_{i}\right)
$$

Dimana:

$\mathrm{T}$ : jumlah waktu pengamatan

$\hat{\lambda}_{i}$ : estimasi eigenvalue yang dihasilkan dari estimasi matriks $\Pi$

$r$ : pangkat yang mengindikasikan jumlah vektor kointegrasi.

Untuk mengetahui jumlah vektor kointegrasi maka ada tiga kasus yang perlu dipertimbangkan yaitu: (1). Jika tingkatan $\Pi=0$, maka tidak ada informasi jangka panjang dan model VAR dalam beda tingkat pertama (first difference) cocok representasi; (2). Jika tingkatan $\Pi$ penuh, maka padalah stasioner dalam levelnya dan VAR dalam first different cocok representasi; dan (3) Jika tingkatan $\Pi$ adalah $0<r<p$, maka $\beta p_{t}$ stasioner sekalipun $p_{t}$ tidak stasioner dan bentuk error correction adalah cukup representasi. Dengan mengetahui jumlah vektor kointegrasi $r$, maka akan diketahui jumlah hubungan kointegrasi antar variabel.

\section{Penentuan Panjang Lag Optimal}

Hal krusial dalam metode ADF ini adalah menentukan panjang kelambanan atau lag optimal (lag). Panjang kelambanan bias ditentukan berdasarkan kriteria AIC atau SIC. Panjang lag optimal dalam variable diperlukan untuk menangkap pengaruh dari setiap variable terhadap variable lain dalam sistem VAR. Untuk memperoleh panjang lag optimal, dilakukan pengujian secara bertahap. Pertama, adalah melihat panjang lag maksimum sistem VAR yang stabil. Stabilitas ini dilihat dari nilai inverse roots karakteristik AR polinomialnya. Suatu sistem VAR dikatakan stabil apabila seluruh roots-nya memiliki modulus lebih kecil dari 1 (satu) dan semuanya terletak dalam unit circle.

Penentuan panjang lag optimal atau panjang lag dengan beberapa kriteria yang ada, seperti Akaike Information Criteria (AIC), Schwartz Information Criteria (SIC), Hannan-Quin Criteria (HQ), Likelihood Ratio (LR), dan Final Prediction Error (FPE). Bila kita menggunakan salah satu criteria dalam menentukan panjang kelambanan maka panjang kelambanan yang optimal terjadi jika nilainilai kriteria di atas mempunyai nilai absolut paling kecil. Sedangkan bila kita menggunakan beberapa criteria maka perlu criteria tambahanya itu adjusted R2 sistem VAR. Panjang lag optimal terjadi jika nilai adjusted R2 adalah paling besar (Widarjono, 2009).

\section{Impulse Response dan Variance Decomposition}

Impulse Response merupakan salah satu analisis penting dalam model VAR. Analisis ini untuk melacak respon dari variabel endogen dalam sistem VAR karena adanya gejolak (shock) atau 
perubahan di dalam variable gangguan (e). Efek shock suatu standar deviasi inovasi ini terhadap nilai sekarang dan nilai yang akan dating dari variabel-variabel endogen model yang diamati. Efek shock suatu variable tidak hanya berpengaruh pada variable itu sendiri tetapi juga ditransmisikan pada variable lainnya melalui struktur dinamis atau struktur lag dalam VAR.

The Cholesky Decomposition atau biasa disebut juga dengan The Variance Decomposition memberikan informasi mengenai variabel inovasi yang relatif lebih penting dalam VAR. Pada dasarnya test ini merupakan metode lain untuk meng-gambarkan sistem dinamis yang terdapat dalam VAR. Tes ini digunakan untuk menyusun perkiraan error variance suatu variabel, yaitu seberapa besar perbedaan antara variance sebelum dan sesudah shock, baik shock yang berasal dari diri sendiri maupun shock dari variabel lain.

\section{HASIL DAN PEMBAHASAN}

Pengujian akar unit yang dilakukan menggunakan program Eviews versi 7. Pengujian akar unit(Unit Root Test) menggunakan Augmented Dickey-Fuller Test dengan tujuan untuk menguji apakah variabel investasi, ekpsor, impor dan pendapatan nasional bersifat stationer atau tidak. Hasil uji unit akar untuk variabel pertumbuhan ekonomi menunjukkan nilai absolut statistik ADF (5.565164) lebih besar daripada nilai kritis MacKinnon pada level kepercayaan sebesar 1\% (3.679322) sehingga dapat dikatakan bahwa shock perubahan pendapatan nasional sudah stasioner (lihat Tabel 1). Pengujian untuk variabel pertumbuhan investasi (INV) menunjukkan bahwa variabel INV memiliki nilai absolut statistik ADF (4.560182) lebih besar daripada nilai kritis MacKinnon pada level kepercayaan sebesar 1\% (3.679322) sehingga dapat dikatakan bahwa data perubahan investasi sudah stasioner pada tingkat level.

Tabel 1. Hasil Uji Akar Unit

\begin{tabular}{cccc}
\hline \multirow{2}{*}{ Variabel } & \multicolumn{3}{c}{ Hasil Pengujian } \\
\cline { 2 - 4 } & Akar Unit & Level & Level kepercayaan \\
\hline PDB & -5.565164 & $1 \%$ & -3.679322 \\
& & $5 \%$ & -2.967767 \\
& & $10 \%$ & -2.622989 \\
\hline INV & -4.560182 & $1 \%$ & -3.679322 \\
& & $5 \%$ & -2.967767 \\
& & $10 \%$ & -2.622989 \\
\hline EKSPOR & -4.160011 & $1 \%$ & -3.679322 \\
& & $5 \%$ & -2.967767 \\
& & $10 \%$ & -2.622989 \\
\hline IMPOR & -4.296365 & $1 \%$ & -3.679322 \\
& & $5 \%$ & -2.967767 \\
& & $10 \%$ & -2.622989 \\
\hline
\end{tabular}

Sumber : Perhitungan EViews

Hasil uji akar unit untuk variabel pertumbuhan ekspor menunjukkan bahwa pertumbuhan ekspor memiliki nilai absolut statistik ADF (4.160011) lebih besar daripada nilai kritis MacKinnon pada level kepercayaan sebesar 1\% (3.679322) sehingga dapat dikatakan bahwa data perubahan ekspor sudah stasioner pada tingkat level. Sementara itu hasil uji akar unit untuk variabel pertumbuhan impor menyatakan bahwa variabel inflasi memiliki nilai absolut statistik ADF 
(4.296365) lebih besar daripada nilai kritis MacKinnon pada level kepercayaan sebesar $1 \%$ (3.679322) sehingga dapat dikatakan bahwa data perubahan impor sudah stasioner pada tingkat level. Dari hasil tersebut maka dapat disimpulkan bahwa seluruh variabel sudah lolos uji akar unit sehingga bisa dilakukan estimasi.

\section{Hasil Uji Kelambanan Var}

Dalam membentuk model VAR, maka lebih lebih awal harus ditentukan dulu berapa jumlah lag yang paling sesuai dengan model. Untuk menentukan jumlah lag yang paling sesuai dengan model, maka kriteria yang di gunakan adalah di dasarkan pada nilai uji Akaike Information Criterion (AIC) dan Schwarz Information Criterion (SIC) yang menghasilkan nilai minimum. Hasil uji kelambanan VAR dapat dilihat pada Tabel 2.

Tabel 2. Hasil Uji Kelambanan VAR

\begin{tabular}{ccccccc}
\hline Lag & LogL & LR & FPE & AIC & SC & HQ \\
\hline 0 & -479.4878 & NA & $4.21 \mathrm{e}+10$ & 35.81391 & $36.00589^{*}$ & $35.87100^{*}$ \\
1 & -462.1084 & $28.32201^{*}$ & $3.86 \mathrm{e}+10^{*}$ & $35.71173^{*}$ & 36.67161 & 35.99715 \\
2 & -447.1163 & 19.98946 & $4.55 \mathrm{e}+10$ & 35.78639 & 37.51417 & 36.30015 \\
3 & -435.8077 & 11.72744 & $8.20 \mathrm{e}+10$ & 36.13390 & 38.62959 & 36.87600 \\
\hline
\end{tabular}

Hasil analisis menunjukkan bahwa nilai $\mathrm{SC}$ dan $\mathrm{HQ}$ pada berada pada lag 0 dan nilai LR, FPE, AIC berada pada lag 1. Dengan demikian jumlah lag yang paling sesuai dengan model adalah lag 1, dengan nilai LR sebesar 28.32201, nilai FPE $3.86 \mathrm{e}+10$ dan nilai AIC sebesar 35.71173. Hasil uji kelambanan menunjukkan bahwa derajat kelambanan variabel-variabel tersebut untuk menjadi stasioner adalah pada lag 1.Dengan demikian dapat disimpulkan bahwa diantara variabel variabel yang dihunakan dalam penelitian tidak ada yang memiliki hubungan kausalitas dua arah, yakni antara pendapatan nasional, investasi, ekspor dan impor .

\section{Hasil Pengujian Impulse Response}

Response to Cholesky One S.D. Innovations \pm 2 S.E.
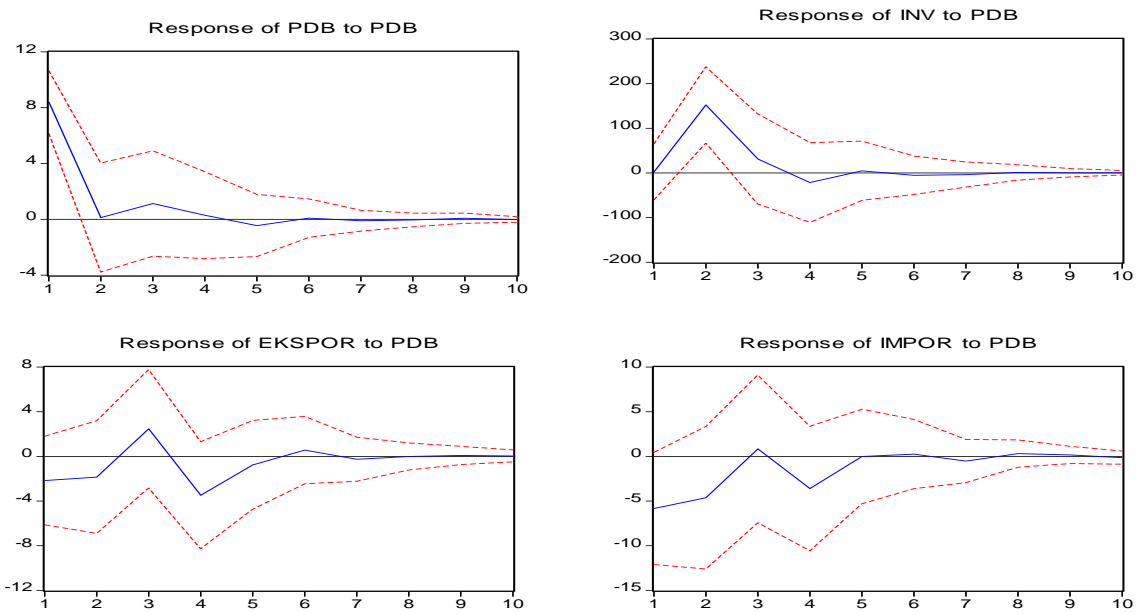

Gambar 3. Respon Investasi, Ekspor dan Impor Terhadap Pendapatan Nasional 
Hasil pengujian impulse response function dapat dilihat Gambar 3. Hasil perhitungan menunjukkan bahwa perubahan investasi mula-mula direspon positif sampai tahun kedua dan selanjutnya direspon negatif sampai tahun ke 4 dan pada akhirnya menuju titik keseimbangan. Sementara itu perubahan ekspor mula-mula direspon direspon positif oleh pendapatan nasional saampai tahun ke 3, namun selanjutnya direspon negatif sampai tahun ke 4 dan menuju ke titik keseimbangan pada tahun ke 10.

Sementara itu perubahan impor mula-mula direspon positif oleh pendapatan nasional sampai tahun ke 3, namun selanjutnya direspon negatif sampai tahun ke 4 dan menuju ke titik keseimbangan pada tahun ke 10.

Variance decomposition memisahkan variasi perubahan shock dari setiap variabel terhadap variabel lain dalam model. Setiap variabel perubahan dalam model diasumsikan tidak berkorelasi. Variance decomposition menggambarkan besarnya sumbangan pengaruh dari suatu variabel perubahan terhadap variabel lain dalam model.

Hasil analisis menyatakan bahwa variance decomposition dari variabel pendapatan nasional menjelaskan bahwa pada periode ke 1 dipengaruhi oleh variabel itu sendiri yaitu 100 persen. Namun mulai periode ke 2 nilainya terus menurun sampai periode 10 menjadi 88,70 persen. Kontribusi shock variabel investasi terhadap pendapatan nasional mula-mula hanya 1,60 persen pada periode ke 2 dan terus mengalami peningktan sampai periode ke-10, hingga menjadi 3,30 persen.

Tabel 3. Hasil Pengujian Variance Decomposition

\begin{tabular}{cccccc}
\hline Period & S.E. & PDB & INV & EKSPOR & IMPOR \\
\hline 1 & 8.410435 & 100.0000 & 0.000000 & 0.000000 & 0.000000 \\
2 & 8.807057 & 91.21542 & 1.608851 & 5.785174 & 1.390553 \\
3 & 8.948849 & 89.94579 & 2.669393 & 5.692710 & 1.692109 \\
4 & 8.993687 & 89.15657 & 3.211405 & 5.943135 & 1.688894 \\
5 & 9.023396 & 88.81410 & 3.241812 & 5.994166 & 1.949917 \\
6 & 9.025077 & 88.79003 & 3.264262 & 5.992191 & 1.953520 \\
7 & 9.028888 & 88.72795 & 3.289076 & 5.988298 & 1.994677 \\
8 & 9.029442 & 88.71944 & 3.296924 & 5.989201 & 1.994435 \\
9 & 9.030611 & 88.70391 & 3.300808 & 5.987777 & 2.007509 \\
10 & 9.030755 & 88.70137 & 3.302502 & 5.988250 & 2.007882 \\
\hline
\end{tabular}
Cholesky Ordering: PDB INV EKSPOR IMPOR

Kontribusi shock variabel ekspor terhadap pendapatan nasional mula-mula hanya sebesar 5,78 persen pada periode ke 2 dan mengalami penurunan pada periode 3 , namun selanjutnya mengalami fluktuasi berupa peningkatan sampai periode ke 6 menjadi 5,99 persen dan menurun pada periode7, meningkat paa periode 8 mrnjadi 5,98 persen. Sementara hasil pengujian variance decomposition untuk variabel impor menyatakan bahwa kontribusi shock variabel impor terhadap pendapatan nasional pada awalnya sekitar 1,39 persen pada periode ke 2, selanjutnya pergerakannya meningat sampai periode ke 10 hingga mencapai 2,01 persen.

\section{Hasil Pengujian Regresi}

Hasil pengujian regresi yang dilakukan menggunakan Eviews 7 menyatakan bahwa pertumbuhan investasi memberikan pengaruh positif namun tidak signifikan terhadap pertumbuhan ekonomi di Indonesia dengan nilai t statistik sebesar 0.2080. Hal ini berarti semakin tinggi 
pertumbuhan ekspor akan dapat meningkatkan pertumbuhan ekonomi. Hasil perhitungan selengkapnya disajikan pada Tabel 4.

Tabel 4. Hasil Perhitungan Regresi

\begin{tabular}{ccccc}
\hline Variable & Coefficient & Std. Error & t-Statistic & Prob \\
\hline C & 17.79712 & 3.015097 & 5.902669 & 0.0000 \\
INVESTASI & 0.001292 & 0.006210 & 0.208039 & 0.8368 \\
EKSPOR & 0.214082 & 0.090593 & 2.363126 & 0.0259 \\
IMPOR & -0.179800 & 0.172418 & -1.042813 & 0.3066 \\
\hline R-squared & 0.092060 & & & \\
\hline Adjusted R-squared & -0.012702 & & & \\
\hline Sun
\end{tabular}

Sumber : Hasil olah data

Hasil positif untuk pertumbuhan ekspor ini sesuai dengan hipotesis yang sudah dikemukakan bahwa pertumbuhan ekspor akan memacu pertumbuhan ekonomi. Beberapa penelitian mendukung argumentasi yang menyatakan bahwa investasi memberikan pengaruh besar terhadap pola perdagangan internasional dan sebagian besar investasi yang masuk ke negara-negara sedang berkembang mampu memberikan peningkatan ekspor (lihat Makki dan Somwaru (2004), Kholis (2012).

Menurut World Investment Report 2002, secara umum investasi dapat meningkatkan ekspor dengan cara: (1) menambah modal dalam negeri untuk ekspor; (2) melakukan transfer teknologi dan produk baru untuk ekspor; (3) memberikan akses kepada pasar yang baru atau pasar asing; (4) menyediakan pelatihan kepada tenaga kerja di dalam negeri yang dapat meningkatkan kemampuan teknis dan skill management. Peningkatan ekspor ini akhirnya dapat meningkatkan pertumbuhan ekonomi yang diukur dengan pertumbuhan GDP suatu negara kemudian berpengaruh pada permintaan uang akibat peningkatan GDP tersebut. Ekspor merupakan faktor penting dalam merangsangpertumbuhan ekonomi suatu negara. Ekspor impor akan memperbesar kapasitas konsumsi suatu negara meningkatkan output dunia, serta menyajikan akses kesumber-sumber daya yang langka dan pasar-pasar internasional yang potensial untuk berbagai produk ekspor yang mana tanpa produk-produk tersebut, maka negara-negara miskin tidak akan mampu mengembangkan kegiatan dan kehidupan perekonomian nasionalnya (Kholis, 2012).

Ekspor juga dapat membantu semua negara dalam menjalankan usaha-usaha pembangunan mereka melalui promosi serta penguatan sektor-sektor ekonomi yang mengandung keunggulan komparatif, baikitu berupa ketersediaan faktor-faktor produksi tertentu dalam jumlah yang melimpah, atau keunggulan efisiensi alias produktifitas tenaga kerja. Ekspor juga dapat membantu semua negara dalam mengambil keuntungan dari skala ekonomiyang mereka miliki (Todaro dan Smith, 2004).

Sebaliknya pertumbuhan impor memberikan pengaruh negatif terhadap pertumbuhan ekonomi masing masing dengan nilai $t$ statistic sebesar -1.042813 . Dengan demikian hasil ini sesuai dengan hipotesis yang dikemukakan bahwa semakin tinggi impor suatu negara cenderung akan menurunkan pertumbuhan ekonominya. Hal ini sesuai dengan kajian yang dilakukan oleh Sodik dan Nuryadin (2005).

Hasil perhitungan menunjukkan bahwa variabel pertumbuhan investasi memberikan pengaruh positif terhadap pertumbuhan ekonomi di Indonesia. Hal ini sesuai sesuai dengan hipotesis yang menyatakan bahwa investasi akan memberikan pengaruh positif terhadap pertumbuhan 
ekonomi. Data yang dihimpun oleh Sekretariat Negara Republik Indonesia (2012) menyebutkan bahwa perkembangan kondisi global pada beberapa tahu terakhir dan terjaganya komponenkomponen pertumbuhan termasuk investasi menempatkan Indonesia pada posisi yang kuat dalam percaturan ekonomi global. Dalam konteks regional kawasan Asia Tenggara, pertumbuhan ekonomi Indonesia paling tinggi dibanding negara lain dalam kelompok ASEAN 5 (Indonesia, Thailand, Malaysia, Filipina, dan Vietnam) yang diprediksi hanya tumbuh 5,4 persen. Dalam kawasan Asia, pertumbuhan ekonomi Indonesia hanya di bawah China, dan bahkan mampu melampaui India.

Dengan demikian Indonesia harus menjaga kelangsungan pertumbuhan investasinya. Banyaknya hambatan masuk bagi investor asing, birokrasi yang kurang efisien dan infrastruktur yang kurang mendukung harus segera dieliminasi karena kebijakan investasiterkait langsung dengan kebijakan industri, perdagangan, dan juga kebijakannon ekonomi lainnya. Pencapaian positif ini sudah selayaknya untuk diapresiasi. Kondisi perekonomian global yang belum pulih dan adanya kemungkinan perluasan intensitas dan skala krisis membuat kita semua harus tetap waspada dan berhati-hati dalam menyikapi perkembangan yang ada. Tetap menjaga kestabilan dan kekuatan fundamental ekonomi melalui peningkatan iklim investasi dengan pembangunan infrastruktur dan pembenahan jalur birokrasi investasi, serta peningkatan kualitas belanja pemerintah menjadi beberapa agenda kebijakan pokok yang harus dijalankan untuk menjaga dan meningkatkan trend serta kualitas pertumbuhan ekonomi.

\section{PENUTUP}

Hasil penelitian menyimpulkan bahwa pertumbuhan ekspor dan pertumbuhan investasi akan memacu pertumbuhan ekonomi. Investasi diyakini akan memberikan pengaruh besar terhadap pola perdagangan internasional dan sebagian besar investasi yang masuk ke negara-negara sedang berkembang mampu memberikan peningkatan ekspor. Ekspor merupakan faktor penting dalam merangsang pertumbuhan ekonomi suatu negara karena akan memperbesar kapasitas suatu negara untuk meningkatkan output dunia. Ekspor juga dapat membantu semua negara dalam mengambil keuntungan dari skala ekonomi yang mereka miliki (Todaro dan Smith, 2004).

Pertumbuhan investasi memberikan pengaruh positif terhadap pertumbuhan ekonomi di Indonesia. Dengan demikian Indonesia harus menjaga kelangsungan pertumbuhan investasinya. Banyaknya hambatan masuk bagi investor asing, birokrasi yang kurang efisien dan infrastruktur yang kurang mendukung harus segera dieliminasi karena kebijakan investasiterkait langsung dengan kebijakan industri, perdagangan, dan juga kebijakannon ekonomi lainnya. Sebaliknya pertumbuhan impor memberikan pengaruh negatif terhadap pertumbuhan ekonomi. Pertumbuhan impor yang tinggi akan meningkatkan aliran uang ke luar ngeri, bahkan bisa menyebabkan terjadinya capital outflow.

Pencapaian positif bahwasanya pertumbuhan ekspor dan pertumbuhan investasi mampu meningkatkan pertumbuhan ekonomi di Indonesia ini sudah selayaknya untuk diapresiasi. Kondisi perekonomian global yang belum pulih dan adanya kemungkinan perluasan intensitas dan skala krisis membuat kita semua harus tetap waspada dan berhati-hati dalam menyikapi perkembangan yang ada. Tetap menjaga kestabilan dan kekuatan fundamental ekonomi melalui peningkatan iklim investasi dengan pembangunan infrastruktur dan pembenahan jalur birokrasi investasi, serta peningkatan kualitas belanja pemerintah menjadi beberapa agenda kebijakan pokok yang harus dijalankan untuk menjaga dan meningkatkan trend serta kualitas pertumbuhan ekonomi.

Beberapa kebijakan juga sudah diambil pemerintah dalam rangka meningkatkan investasi terutama investasi asing langsung di Indonesia. Pemerintah melalui Badan Koordinasi dan 
Penanaman Modal (BKPM) telah melakukan beberapa upaya penyesuaian kebijakan investasi, di antaranya adalah sebagai berikut:

1. Pemerintah telah memperbaharui daftar bidang usaha yang tertutup bagi penanam modal untuk dapat diberikan keleluasaan investor dalam memilih usaha (Keppres № 96 Tahun 2000 jo. № 118 Tahun 2000). Dalam keputusan tersebut, bidang usaha yang tertutup untuk investasi baik Penanaman Modal Asing (PMA) maupun Penanaman Modal Dalam Negeri (PMDN) berkurang dari 16 sektor menjadi 11 sektor. Bidang usaha yang tertutup bagi kepemilikan saham asing berkurang dari 9 sektor menjadi 8 sektor.

2. Penyederhanaan proses dari 42 hari menjadi 10 hari. Sebelumnya persetujuan Penanaman Modal Asing (PMA) dilakukan oleh Presiden, sedangkan saat ini cukup dilakukan oleh Pejabat Eselon I yang berwenang, dalam hal ini Deputi Bidang dan Fasilitas Penanaman Modal.

3. Sejak tanggal 1 Januari 2001, pemerintah menggantikan insentif Pembebasan Pajak dengan Kelonggaran Pajak Investasi sebesar 30\% untuk 6 (enam) tahun.

4. Nilai investasi tidak dibatasi, sepenuhnya tergantung studi kelayakan dari proyek tersebut.

Undang-Undang Penanaman Modal No.25 tahun 2007 dapat dikatakan sudah mencakup semua aspek penting (termasuk soal pelayanan, koordinasi, fasilitas, hak dan kewajiban investor, ketenagakerjaan, dan sektor-sektor yang bisa dimasukin oleh investor) yang terkait erat dengan upaya peningkatan investasi dari sisi pemerintah dan kepastian berinvestasi dari sisi pengusaha atau investor.

\section{REFERENSI}

Akhmetova. Sharzada, Gulzada Baimukhamedova \& Jung-Wan Lee. (2010). Foreign Direct Investment, Exchange Rate, And Their Roles In Economic Growth Of Developing Countries: Empirical Evidence From Kazakhstan. Journal of International Business Research. 9.2 (July 2010): p.75.

Alfaro, L., A. Chandra, S. Kalemli-Ozcan, \& S. Sayek. (2000). FDI and Economic Growth: The Role of Local Financial Markets. Harvard Business School, Working Paper 01-083

Borensztein, E., J. De Gregorio, J.W. Lee. (1998). How Does Foreign Direct Investment Affect Economic Growth? Journal of International Economics, 45, pages 115--35.

Effendi, Nury \& Soemantri Femmy M. (2003). Foreign Direct Investment and Regional Economics Growth in Indonesia: A Panel Data Study. Working paper in Economics and Development Studies. Diakses pada tanggal 4 Januari 2011dari web: http://www.lp3e-unpad.org.

Ghani, Ejaz \& Musleh-Ud Din. (2006). The Impact Of Public Investment On Economic Growth In Pakistan. The Pakistan Development Review 45 : 1 (Spring 2006) pp. 87-98. Di download pada tanggal 24 Februari 2012 dari web http://www.pide.org.pk/pdf/PDR/2006/Volume1/8798.pdf.

Gharana, Kishor.K \& Deergha R. Adhikari. (2011). Econometric Investigation Of Relationship Among Export, FDI And Growth In China: An Aplication Of Toda Yamamoto-Dolado-Lutkephol Granger Causality Test. Journal of International Business Research, vol. 10, Number 2. 2011

Hadi, Y. S. (2003). Analisis Vector Auto Regression (Var) Terhadap Korelasi Antara Pendapatan Nasional Dan Investasi Pemerintah di Indonesia, 1983/1984-1999/2000. Jurnal Keuangan dan Moneter, vol.6. Nomor 2. Desember 2003. Di download di pada tanggal 2 Februari 2012 dari werb http://www. fiskal.depkeu.go.id/2010/adoku/7.Jonatan-2.pdf.

Hamid, Edy S. (2008). Perekonomian Indonesia. Pusat Penerbit Universitas Terbuka. 
Kholis, Muhamad. (2012). Dampak FDI terhadap Pertumbuhan Ekonomi di Indonesia. Jurnal Organisasi dan Manajemen, vol. No.2. September 2012

Lestari, E.P. (2005). Pengaruh volatilitas nilai tukar rupiah terhadap permintaan uang M1 Indonesia, estimasi data non stasioner. Jurnal Ekonomi Pembangunan, vol.10(2) hal. 143-155.

Liu, X., C. Wang \& Y. Wei. (2001). Causal Links Between Foreign Direct Investments And Trade in China. China Economic Review, 12, 190-202.

Makki, S.S \& Somwaru, A. (2004). Impact of Foreign Direct Investment and Trade on Economic Growth: Evidence from Developing Countries.American Journal of Agricultural Economics, vol.86 (3):795-801

Rao. Bhaskara. (2004). The Relationship Between Growth and Investment_Growth \& Investment, Paper. Di download pada tanggal 27 Februari 2012 dari web http://129.3.20.41/eps/macl papers/0511/0511014.pdf.

Sumanun, P. (1994). Effect of Foreign Direct Investment on Economic Growth and Modernization in Developing Countries: A Time Series and Cross-National Analysis, Dissertation, The University of Texas at Dallas.

Todaro, Michael \& Stephen C. Smith. (2006). Pembangunan Ekonomi: Edisi Sembilan. Penerbit Erlangga. Jakarta.

Widarjono, A. (2009). Ekonometrika Pengantar dan Aplikasinya. Yogyakarta: Penerbit Ekonisia Fakultas Ekonomi UII.

Wikipedia. (2012). Pertumbuhan Ekonomi. Di download pada tanggal 27 Februari 2012 dari web http://id.wikipedia.org/wiki/Pertumbuhan_ekonomi. 